\title{
Budidaya Kambing Etawa Di Jorong Padang Ambacang Nagari Batu Balang Kecamatan Harau Kabupaten Lima Puluh Kota
}

\author{
Rusdi *), Wahidul Basri, Aldi Frinaldi, Uun Lionar \\ Fakultas Ilmu Sosial - Universitas Negeri Padang \\ *)Corresponding author, $\equiv$ rusdi64@ fis.unp.ac.id
}

Revisi 15/07/2019;

Diterima 20/08/2019;

Publish 05 /09/2019

Kata kunci: Budidaya, Kambing Etawa, Jorong Padang Ambacang.

\begin{abstract}
Abstrak
Kebanyakan penduduk desa menjalankan usaha beternak kambing secara rumahan dan tradisional, sehinggga hasilnya kurang maksimal. Sistem yang digunakan adalah usaha sampingan yang tidak dikerjakan secara intensif. Mereka beternak kambing hanya beberapa ekor tanpa target omset apapun. Padahal kalau ditekunni secara modernn serius potensi usaha peternakan kambing di desa sangatlah besar. Supaya usaha ternak kambing cepat berhasil menggunakan cara beternak kambing secara modern dan propfesional seperti fermentasi pakan ternak kambing termasuk cara beternak kambing yang baik dan benar. Cara berternak kambing di desa mitra yakni di Jorong Padang Ambacang Nagari Batu Balang Kecamatan Harau Kabupaten Lima Puluh Kota, pada umumnya masih menggunakan cara lama yang bersifat tradisional, sehingga keuntungan yang didapatkan kurang maksimal. Permasalahan mitra 1 sebagai pengusaha mikro yang bergerak dalam bidang perternakan kambing etawa masih bersifat tradisional. Untuk itu, perlu pengembangan usaha pertenakannya seperti fermentasi pakan dan menerapkan manajemen pertenakan. Permasalahan mitra 2 adalah, disamping permasalahan manajemen pertenakan kambing juga perlu pendampingan dan permodalan untuk memulai usaha pertenakan kambing etawa. Melalui penerapan teknologi dan inovasi terkini, cara ternak kambing modern dinyatakan lebih intensif. Berikut beberapa cara ternak kambing modern yang perlu diterapkan sebagai solusi permasalahan mitra, diantaranya manajemen kandang kambing, manajemen bibit kambing, manajemen pakan kambing, dan manajemen pemeliharaan kambing. Skema pelaksanaan kegiatan program Ipteks yang dilakukan bersama kedua mitra difokuskan pada dua bidang, yaitu penerapan teknologi tepat guna dan perbaikan manajemen usaha. Skema pelaksanaan penerapan teknologi tepat guna adalah teknik pembuatan pakan alternatif/buatan (fermentasi). Sedangkan kegiatan perbaikan manajemen usaha diwujudkan dalam bentuk pelatihan. Pelatihan yang dilaksanakan adalah pelatihan manajemen kandang kambing, manajemen bibit kambing, manajemen pakan kambing, dan manajemen pemeliharaan kambing
\end{abstract}




\section{Suluah Bendang: Jurnal Ilmiah Pengabdian Kepada Masyarakat}

Vol19, No.2, 2019

Rusdi, Wahidul Basri, Aldi Frinaldi, Uun Lionar

\section{PENDAHULUAN}

\section{Analisis Situasi}

Kebanyakan penduduk desa menjalankan usaha beternak kambing secara rumahan dan tradisional. Sehinggga kurang maksimal. Kita bisa dengan mudah menemukan banyak kandang kambing di samping rumah warga desa. Sistem yang digunakan adalah usaha sampingan yang tidak dikerjakan secara intensif. Mereka beternak kambing hanya beberapa ekor tanpa target omset apapun. Padahal kalau ditekunni secara modernn serius potensi usaha peternakan kambing di desa sangatlah besar. Supaya usaha ternak kambing dapat cepat berhasil menggunakan cara beternak kambing secara modern dan propfesional seperti fermentasi pakan ternak kambing termasuk cara beternak kambing yang baik dan benar. Peternakan kambing adalah salah satu lahan produksi yang dibutuhkan pasar kuliner untuk menyuplai bahan makanan olahannya. Usaha budidaya kambing masih menjadi peluang bisnis menguntungkan yang banyak dilirik orang. Di pedesaan terpencil di Indonesia, kita dapat dengan mudah menjumpai berbagai gerai peternakan kambing. Baik secara tradisional, kecilkecilan, skala rumahtangga, menengah hingga skala besar. Adapun kambing yang diternakkan dari berbagai macam jenis kambing. Seperti kambing gembel, gibas, etawa, jawa hingga garut. Namun untuk memulai usaha beternak kambing secara sukses tidak sembarangan terutama bagi pemula. Diperlukan ilmu cara ternak kambing yang menguntungkan.

Usaha beternak kambing mempunyai kekurangan dan kelebihan masing-masing. Kelemahannya adalah memerlukan perawatan ekstra. Sehingga tidak bisa ditinggalkan begitu saja walau satu hari. Namun keunggulannya sangat banyak, seperti setelah kambing bertambah gemuk dalam waktu satu tahun maka kambing bisa dijual dengan harga tinggi. Kambing termasuk jenis hewan ternak yang paling menguntungkan dalam waktu singkat. Umur satu tahun kambing betina bisa melahirkan beberapa anak kambing. Sehingga dalam jangka waktu empat tahun bisa beranak pinak hingga delapan ekor. Selain itu, jika peternak membutuhkan uang dalam jumlah besar secara mendadak maka ia bisa menjual kambing secara cepat. Biasanya para pengumpul datang kepada para peternak untuk membeli kambing. Apa lagi pada saat hari raya Idul Adha, menjual kambing sangat mudah, sebab banyak orang membutuhkan kambing untuk hewan korban.

Usaha beternak kambing sangat menyenangkan, sebab bagaimanapun konsep dalam budidaya kambing pasti akan selalu menguntungkan. Baik konsep beternak kambing tradisional, modern, hingga skla rumah tangga. Sebetulnya usaha ternak kambing bisa dilaksanakan di kota maupun di desa. Namun akan lebih menjanjikan dan mendukung untuk berbisnis ternak kambing di pedesaan. Karena sumber daya alam yang mendukung sekali. Seperti ketersediaan pakan alami berupa dedaunan bagi kambing yang bisa cepat gemuk, lahan yang masih luas sehingga kandang kambing tidak mengganggu warga sekitar. Tim pengusul PKM melihat dan mengamati cara berternak kambing di desa mitra yakni di Jorong Padang Ambacang Nagari Batu Balang Kecamatan Harau Kabupaten Lima Puluh Kota, pada umumnya masih menggunakan cara lama yang bersifat tradisional. Sehingga keuntungan yang didapatkan kurang maksimal. Sedangkan di negara maju di berbagai dunia seperti Amerika Serikat, Brazil dan negara lainnya telah mengembangkan cara beternak kambing secara modern yang cepat berhasil memakai teknik pakan fermentasi. 
Salah satu hal yang paling utama dalam proses beternak kambing yang cepat menguntungkan adalah pemberian pakan secara teratur. Berdasarkan pengalaman seringkali peternak kambing mengeluhkan sulitnya mendapatkan pakan alami jika sedang musim kekeringan. Atau jika pakan tersedia banyak ketika musim hujan maka merasakan kelelahan dalam memberikan pakan kambing setiap hari. Itulah resiko dari beternak kambing, sama seperti menjalankan pekerjaan dan usaha lain.

Untuk itulah, saat ini ada cara modern beternak kambing yang cukup mudah dan mengntungkan yaitu ternak menggunakan pakan fermentasi sehingga tanpa ngarit setiap hari. Cara ini belum diketahui para peternak kambing di seluruh desa dan kota di tanah air termasuk di desa mitra yakni Jorong Padang Ambacang Nagari Batu Balang Kecamatan Harau Kabupaten Lima Puluh Kota. Pada hal kalau dikembangkan teknik ini mampu mendatangkan keuntungan lebih optimal dengan lebih mudah dalam pemeliharaan kambing.Jenis kambing etawa sering disebut kambing PE yang merupakan hasil persilangan. Adapun ciri atau tanda dari kambing peranakan etawa dapat dilihat dari bulunya yang memiliki warna coklat muda hingga hitam, mempunyai telinga terkulai yang panjang rata-rata 20 sentimeter. Kambing jantan mempunyai bulu yang lebih tebal dan berat hingga 40 kilogram, adapun kambing etawa betina sebesar 35 kilogram. Dalam Program Kemitraan Masyarakat (PKM) ini tim pengusul membudidayakan ternak kambing etawa di Jorong Padang Ambacang Nagari Batu Balang Kecamatan Harau Kabupaten Lima Puluh Kota dengan pertimbangan, kelebihan beternak kambing etawa antara lain:

\section{Pasar luas}

Keunggulan usaha budidaya kambing etawa yang utama adalah memiliki pangsa pasar yang sangat luas. Setiap orang pasti membutuhkan kambing untuk komsumsi maupun piaraan. Misalkan menjelang hari raya idul adha, setiap muslim membutuhkan hewan kambing untuk dijadikan binatang korban. Kemudian untuk menyelenggarakan akikah, setiap orang tua yang mempunyai bayi laki-laki maka ia harus menyemblih dua ekor kambing. Yang kemudian daging kambing dibagikan kepada sanak kerabat dan tetangga.

\section{Mudah dijual}

Selain itu, kambing sangat mudah dijual, biasanya di setiap desa ada pengepulnya. Bila kita butuh uang, maka kita dapat menjual kepada pengepul tersebut. Biasanya oleh pengepul kambing tersebut dipelihara lagi dan dibesarkan kembali hingga harganya naik dari tahun ke tahun. Dari sinilah jelas usaha beternak kambing etawa akan selalu menguntungkan.

\section{Menguntungkan}

Usaha beternak kambing etawa merupakan ternak hewan yang paling menguntungkan dalam waktu singkat. Yang diambil manfaat dari kambing bukan hanya daging tapi juga susu dan kotorannya. Susu kambing banyak dicari orang karena terbukti mampu mengobati berbagai penyakit. Dan kotoran kambing sangat bagus untuk pupuk. Permintaan akan daging dan susu kambing cukup besar di Indonesia. Dan para peternak kambing lokal belum mampu memenuhi permintaan pasar tersebut. Sehingga pemerintah terpaksa melakukan impor daging dan susu kambing.

\section{Mudah dipelihara}

Kelebihan lain, kambing etawa yang asal usulya berasal dari negara India ini sangat mudah dipelihara. Apalagi seiring dengan berkembangnya teknologi pemberian pakan fermentasi. Sehingga usaha beternak kambing etawa bisa tanpa ngarit. Kita bisa membuka usaha ternak 


\section{Suluah Bendang: Jurnal Ilmiah Pengabdian Kepada Masyarakat}

Vol19, No.2, 2019

Rusdi, Wahidul Basri, Aldi Frinaldi, Uun Lionar

kambing etawa secara rumahan maupun kecil-kecilan dengan teknik modern. Dari analisa sistuasi di atas jelas sekali bahwa ternak kambing potong etawa, tanpa ngarit akan selalu menguntungkan. Mengingat pertumbuhan jumlah penduduk di tanah air meningkat pesat. Mereka membutuhkan kambing untuk kebutuhan acara akikah, komsumsi daging kambing, ibadah idul kurban di hari raya idul adha dan lain sebagainya. Adapun pasokan jumlah kambing dari para peternak jumlahnya sangat terbatas, hal ini membuat peluang usaha budidaya kambing etawa menjanjikan sekali.

\section{Permasalahan Mitra}

Permasalahan mitra 1 sebagai pengusaha mikro yang bergerak dalam bidang perternakan kambing etawa dalam pelaksanaan pertenakannya masih bersifat tradisional, walaupun sudah memakai sistem kandang sederhana, akan tetapi belum menerapkan manajemen kandang kambing, manajemen bibit kambing, manajemen pakan kambing, dan manajemen pemeliharaan kambing. Untuk itu, mitra 1 ini perlu pengembangan usaha pertenakannya dengan menerapkan keempat manajemen pertenakan kambing tersebut. Permasalahan mitra 2 sebagai calon wirausaha baru adalah, disamping permasalahan manajemen pertenakan kambing tersebut juga perlu pendampingan dan permodalan untuk memulai usaha pertenakan kambing etawa.

\section{METODE PELAKSANAAN}

Melalui Program Kemitraan Masyarakat (PKM) ini dan berdasarkan analisis kebutuhan yang telah dilaksanakan, tim pengabdi menawarkan solusi terhadap permasalahan tersebut dengan sentuhan Ipteks sebagaimana diuraikan pada bagian sebelumnya. Skema pelaksanaan kegiatan program Ipteks yang dilakukan bersama kedua mitra difokuskan pada dua bidang, yaitu penerapan teknologi tepat guna dan perbaikan manajemen usaha.

Skema pelaksanaan Rencana penerapan teknologi tepat guna adalah teknik pembuatan pakan alternatif/buatan (fermentasi). Sedangkan kegiatan perbaikan manajemen usaha diwujudkan dalam bentuk pelatihan. Pelatihan yang telah dilaksanakan adalah pelatihan manajemen kandang kambing, manajemen bibit kambing, manajemen pakan kambing, dan manajemen pemeliharaan kambing.

\section{HASIL DAN PEMBAHASAN}

\section{Solusi}

Usaha peternakan kambing saat ini masih banyak yang bersifat usaha sampingan dan dilakukan secara tradisional. Hal ini sangat disayangkan, mengingat peluang usaha ternak kambing masih terbuka lebar dan sangat menguntungkan. Cara ternak kambing modern merupakan jawaban dari tingginya permintaan daging kambing dipasaran. Selain itu, beternak kambing secara modern memiliki banyak keunggulan, diantaranya yaitu efisiensi biaya, waktu, tenaga kerja, pakan dan manajemen pengelolaan. Ternak kambing modern ini dapat diterapkan dalam berbagai skala usaha, mulai dari skala usaha kecil menengah, hingga ternak kambing modern merupakan jawaban dari tingginya permintaan daging kambing dipasaran.

Usaha ternak kambing saat ini dapat dilakukan oleh siapa saja dan dimana saja. Hal ini dikarenakan ternak kambing modern memiliki perbedaan pakan dan pengelolaan jika 
dibandingkan dengan ternak kambing tradisional. Sehingga tidak membutuhkan persyaratan ataupun kriteria tertentu selayaknya ternak kambing tradisional. Melalui penerapan teknologi dan inovasi terkini, cara ternak kambing modern dinyatakan lebih intensif. Berikut beberapa cara ternak kambing modern yang perlu diterapkan sebagai solusi permasalahan mitra, diantaranya manajemen kandang kambing, manajemen bibit kambing, manajemen pakan kambing, dan teknik pembuatan fermentasi pakan kambing, serta manajemen pemeliharaan kambing, selanjutnya diuraikan kelima hal tersebut sebagai berikut:

\section{Manajemen Kandang Kambing}

Kandang kambing adalah salah satu kebutuhan utama pada usaha peternakan kambing. Kandang kambing berfungsi sebagai tempat istirahat, pelindungi dari hewan pemangsa terutama anjing, sebagai tempat makan dan minum, sebagai tempat untuk kawin dan beranak, tempat penampungan kotoran dan kencing, dan untuk mempermudah pengelolaan ternak kambing. Ada 3 hal yang perlu dilakukan dalam manajemen kandang kambing: (a). Syarat Kandang Kambing. Ada banyak hal yang perlu diperhatikan dalam menentukan lokasi kandang kambing. diantaranya adalah : (1) Tempat yang cukup tinggi dan terhindar dari genangan air; (2) Jaraknya cukup jauh dari rumah atau sumur; (3) Mendapatkan cukup sinar matahari pagi; dan (4) Terlindung dari tiupan angin langsung (terutama pada malam hari).

(b) Ukuran Kandang Kambing. Ukuran kandang kambing yang dibutuhkan untuk usaha ternak kambing modern sangat efisien, karena tidak perlu terlalu besar. Sehingga dapat menghemat ruang dan biaya pembuatan kandang, ukuran kandang kambing adalah $3 \times 1,5$ meter untuk 10 ekor kambing. Kandang pada peternakan kambing modern tidak membutuhkan ukuran yang besar, hal ini dikarenakan pakan yang diberikan sangat menghemat ruang. Selain ukurannya yang berbeda, pemeliharan kebersihan kandang kambing juga dirasa lebih mudah. Kebersihan kandang kambing dirasa lebih mudah karena didukung oleh bentuk kandang yang kecil dengan lantai panggung. Ukuran kandang kambing yang relatif kecil dengan populasi maksimal akan mengurangi ruang gerak atau aktivitas pada ternak kambing. Hal itu bermanfaat pada transformasi pakan menjadi cadangan energi berupa daging, lemak, dan sedikit yang menjadi kotoran. Sehingga tidak banyak pakan yang terbuang karena aktivitas gerak, yang otomatis dapat mempercepat penggemukan pada kambing.

(c) Perawatan Kandang Kambing. Perawatan kandang kambing mutlak harus dilakukan pada ternak kambing modern. Seluruh bagian pada kandang kambing harus dibersihkan secara rutin. Seperti membersihkan lantai kandang, kokopan tempat pakan kambing serta memperbaiki sesegera mungkin jika terdapat bagian kerusakan pada kandang kambing. Jenis kandang kambing yang direkomendasikan adalah jenis kandang panggung karena memiliki keunggulan: (1) Kebersihan kandang lebih terjaga, karena kotoran dan air kencing jatuh ke bawah; (2) Kandang kering, sehingga penyakit yang disebabkan oleh parasit dan jamur tidak mudah; dan (3) Terhindar dari serangan hewan liar, seperti anjing atau yang lainnya.

\section{Manajemen Bibit Kambing}

Pemilihan bibit kambing (cempe) yang baik akan sangat menentukan keberhasilan pada usaha penggemukan ternak kambing. Bibit kambing penggemukan yang baik adalah: (1) Berumur lebih dari 6 bulan; (2) Berekor gemuk (bukan berbentuk cambuk); (3) Badan panjang, jantan (lebih diutamakan); dan (4) Tegap dan sehat. Anak kambing yang berusia $>6$ bulan dipilih karena pada usia ini sudah memasuki periode pembentukan daging sehingga lebih cepat gemuk. Anak kambing yang berusia kurang dari 6 bulan tidak digunakan karena masih dalam periode pembentukan tulang sehingga butuh waktu lama untuk proses penggemukan. 


\section{Suluah Bendang: Jurnal Ilmiah Pengabdian Kepada Masyarakat}

Vol19, No.2, 2019

Rusdi, Wahidul Basri, Aldi Frinaldi, Uun Lionar

\section{Manajemen Pakan Kambing}

Keunikan kambing sebagai hewan ruminansia yaitu sistem pencernaan yang mplek (poligastrik). Sistem pencernaan ini mampu mengubah bahan pakan berserat tinggi (rumput, jerami, dll.) sebagai sumber utama energi dan mengubah senyawa nitrogen yang bukan protein (NBP). Contohnya pengubahan urea menjadi protein bernilai bilogis tinggi untuk kebutuhan produksinya. Pakan kambing yang diberikan pada ternak kambing modern, khususnya penggemukan dapat berupa hijauan, konsentrat ataupun pakan fermentasi. Fermentasi pakan kambing ini berguna sebagai pengganti makanan ternak (PMT).

Kombinasi pakan kambing yang baik yaitu kombinasi antara fermentasi pakan kambing dan konsentrat. Fermentasi pakan kambing dan konstrat dapat memenuhi kebutuhan protein dan serat kasar yang sangat dibutuhkan dalam proses penggemukan kambing. Fermentasi juga sangat berguna untuk menyeimbangkan pengeluaran yang tinggi dari pakan konsentrat (Efisiensi). Hal ini dikarenakan pakan fermentasi adalah pakan yang bisa didapatkan dengan harga murah.

Penggunaan pakan secara efisien diukur berdasarkan rasio antara jumlah pakan yang dikonsumsi kambing dengan output yang dihasilkan. Cara untuk mengefisiensi penggunaan pakan kambing dapat dicapai dengan pengelolaan pakan yang tepat. Antara lain pengelolaan alokasi jumlah pakan optimal, formulasi konsentrat yang efisien, pemilihan bahan baku yang seimbang secara nutrisi dan layak secara ekonomis serta penentuan waktu dan frekuensi pemberian pakan yang strategis. Kontribusi penggunaan pakan kambing secara efisien sangat besar terhadap efisiensi ekonomik usaha produksi secara keseluruhan.

\section{Teknik Pembuatan Fermentasi Pakan Kambing}

Fermentasi pakan kambing bisa didapatkan dari limbah pertanian dan limbah organik di sekitar kita. Sisa limbah pertanian atau industri pengolahan pertanian yang dapat difermentasi dan digunakan sebagai pakan dasar pada kambing yaitu kulit kopi, kulit kakao, kulit markisa, kulit nenas, jerami, dan masih banyak lagi. Berikut cara membuat, alat dan bahan yang digunakan untuk fermentasi pakan kambing dengan bahan dasar jerami padi.Bahan Fermentasi Pakan Kambing: 100 kg jerami padi, 0,5 Kg Molases, 1 liter Suplemen Organik Cair GDM Spesialis Ternak, dan Air secukupnya. Sedangkan Alat Fermentasi Pakan Kambing: Pisau/alat pencacah jerami, Drum/wadah tertutup, Bak/wadah terbuka. Adapun cara Membuat Pakan Fermentasi Kambing: (1) Cuci jerami dengan air mengalir. Ini berguna untuk menghilangkan kotoran yang dapat mengganggu proses fermentasi pakan; (2) Kering anginkan jerami hingga dirasa kadar airnya sedikit berkurang dan terhindar dari kotoran-kotoran yang dapat mengganggu proses fermentasi; (3) Cacah kasar jerami padi berukuran sekitar 8-10 cm. Jangan cacah jerami terlalu kecil, karena ukuran yang terlalu kecil dapat menurunkan nafsu makan kambing; (4) Masukkan jerami kedalam bak/wadah terbuka yang cukup besar; (5) Tambahkan Molases, 1 liter Suplemen Organik Cair GDM Spesialis Ternak, dan air secukupnya; (6) Aduk aduk hingga dirasa jerami dan bahan tambahan telah tercampur merata; (7) Masukkan kedalam wadah tertutup, kemudian simpan dan diamkan selama satu minggu; (8) Setelah satu minggu, pakan fermentasi sudah dapat digunakan. 
Pada proses fermentasi pakan kambing, peran bakteri sangatlah penting. Tanpa adanya bakteri yang berfungsi untuk membantu proses fermentasi, maka fermentasi tidak akan berhasil. Penggunaan suplemen organik cair yang mengandung 5 jenis bakteri baik sangat berguna untuk membantu proses fermentasi pakan kambing. Jenis bakteri yang terkandung dalam Suplemen Organik Cair GDM Spesialis Ternak adalah Bacillus brevis, Bacillus pumillus, Bacillus mycoides, Pseudomonas alcaligenes, dan Micrococcus roseus. Kelima bakteri ini sangat dibutuhkan dalam proses pembuatan fermentasi dari berbagai bahan organik, seperti jerami, kulit singkong biji kakao, kulit markisa, kulit nenas dan lainnya. Suplemen Organik Cair GDM Spesialis Ternak mendapatkan sertifikasi dari Komite Akreditasi Nasional (KAN), International Accreditation Forum (IAF) dan Lembaga Sertifikasi Organik Seloliman (LeSOS). Fermentasi pakan kambing bisa didapatkan dari limbah pertanian dan limbah organik di sekitar kita.

\section{Manajemen Pemeliharaan Kambing}

Cara ternak kambing modern harus dengan manajemen pemeliharaan kambing yang baik. Manajemen pemeliharaan terdiri atas pemberian pakan, perawatan ternak, dan menjaga kesehatan ternak. (1) Pemberian Pakan. Frekuensi pemberian pakan bergantung pada jenis pakan yang diberikan. Hal yang terpenting adalah kebutuhan pakan terpenuhi dan diberikan secara rutin dengan mempertimbangkan kandungan nutrisi dari pakannya. (2) Perawatan Ternak Kambing. Perawatan ternak sangat dibutuhkan untuk menjamin keberhasilan upaya penggemukan ternak kambing modern. Hal ini sedikit berbeda dengan ternak tradisonal yang perawatan ternaknya tidak begitu diperhatikan. Perawatan ternak bisa berupa pencukuran bulu, pemotongan kuku, dan perawatan lainnya. (3) Memandikan Ternak Kambing. Memandikan ternak kambing sekurang-kurangnya 2 kali dalam setahun. Ternak yang kotor karena tidak pernah dimandikan lebih mudah terserang penyakit yang disebabkan oleh bakteri dan jamur. Tujuan dari memandikan ternak atau memotong kukunya adalah agar penyakit yang berasal dari parasit dan jamur yang bersarang pada kuku atau bulunya dapat dicegah/diberantas. Selain itu, ternak yang nampak bersih akan terlihat lebih sehat dan menarik, sehingga memiliki harga jual yang lebih tinggi. (4) Penambahan Suplemen Ternak Kambing. Cara ternak kambing yang paling penting dan harus diperhatikan yaitu penambahan suplemen organik cair. Suplemen untuk ternak kambing harus aman dan tidak menimbulkan efek samping dalam jangka panjang. Fungsi dari suplemen ini adalah untuk meningkatkan kekebalan tubuh hewan agar tidak mudah terserang penyakit akibat bakteri, virus, atau jamur yang merugikan. Dengan begitu, maka kematian ternak juga dapat diminimalisir. Selain itu, suplemen juga berfungsi sebagai perangsang dalam mempercepat pertumbuhan ternak, sehingga usaha penggemukan ternak bisa lebih menguntungkan. Suplemen yang memenuhi kriteria tersebut adalah Suplemen Organik Cair GDM, mengandung: (a) Benefical Mocroorganism (bakteri menguntungkan), sehingga mencegah penyakit akibat bakteri, jamur, atau virus masuk kedalam tubuh ternak; (b) Bakteri yang terkandung dalam SOC GDM berfungsi sebagai pendukung untuk memfermentasi pakan; (c) Mengandung unsur nabati dan hewani yang sangat dibutuhkan oleh ternak; (d) Dapat menciptakan antibodi/kekebalan tubuh, sehingga ternak tidak mudah terserang penyakit; (e) Memperbaiki metabolisme, sehingga pertumbuhan ternak menjadi optimal dan besar; (f) Kotoran ternak menjadi tidak bau, karena proses pencernaan ternak dibantu oleh Benefical Mocroorganism; (g) Ramah lingkungan, karena 100\% organik; (h) Aman digunakan dalam jumlah besar dan dalam jangka panjang; (i) Meningkatkan kemampuan ternak dalam mencerna pakan; (l) Meningkatkan nafsu makan ternak dan menjaga keseimbangan mikroflora dalam pencernaan ternak. Begitu banyaknya manfaat dari Suplemen Organik Cair GDM ini, tentu sebagai peternak kambing sangat perlu menambahkan kedalam list dalam perawatan ternak kambing modern. 


\section{Suluah Bendang: Jurnal Ilmiah Pengabdian Kepada Masyarakat}

Vol19, No.2, 2019

Rusdi, Wahidul Basri, Aldi Frinaldi, Uun Lionar

\section{B. Pelaksanaan Kegiatan}

Dalam rangka melaksanakan tugas Tri Dharma Perguruan Tinggi, Tim dosen Universitas Negeri Padang (UNP) telah melaksanakan kegiatan Pengabdian Kepada Masyarakat tentang: "Budidaya Kambing Etawa di Jorong Padang Ambacang Nagari Batu Balang Kecamatan Harau Kabupaten Lima Puluh Kota”.

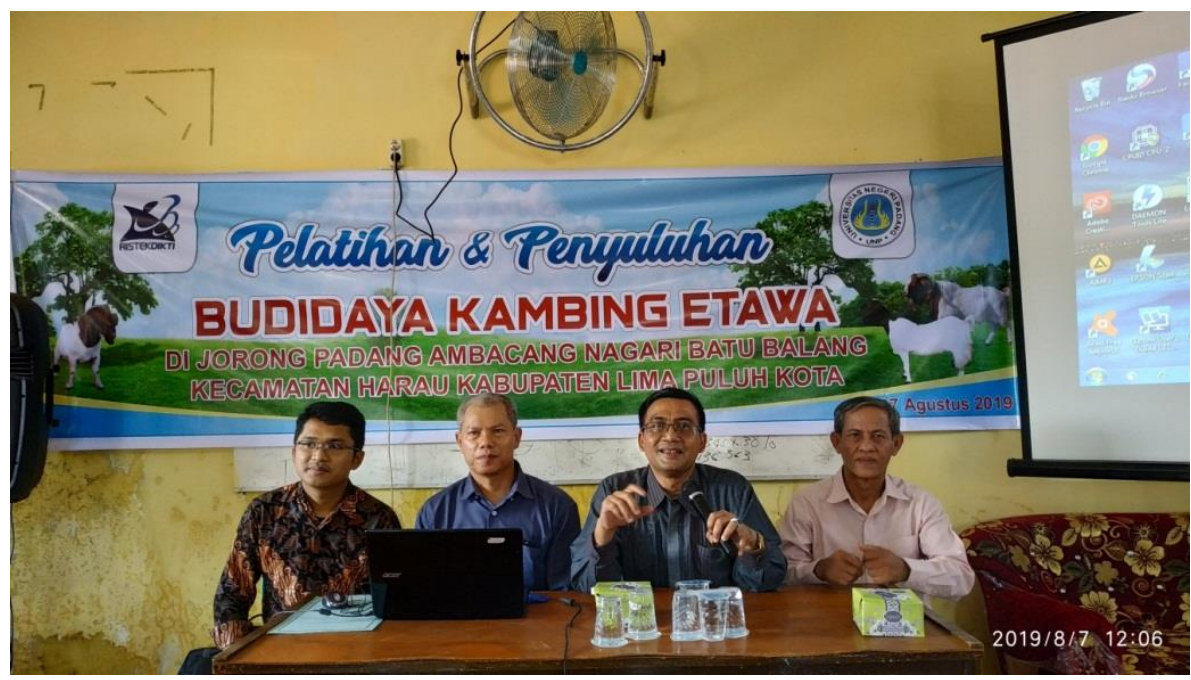

Gambar 1. Tim Pelaksana pengabdian UNP dari kiri: Uun Lionar, M.Pd, Dr. Rusdi, M.Hum, Aldi Frinaldi, M.Hum, Ph.D dan Drs. Wahidul Basri, M.Pd

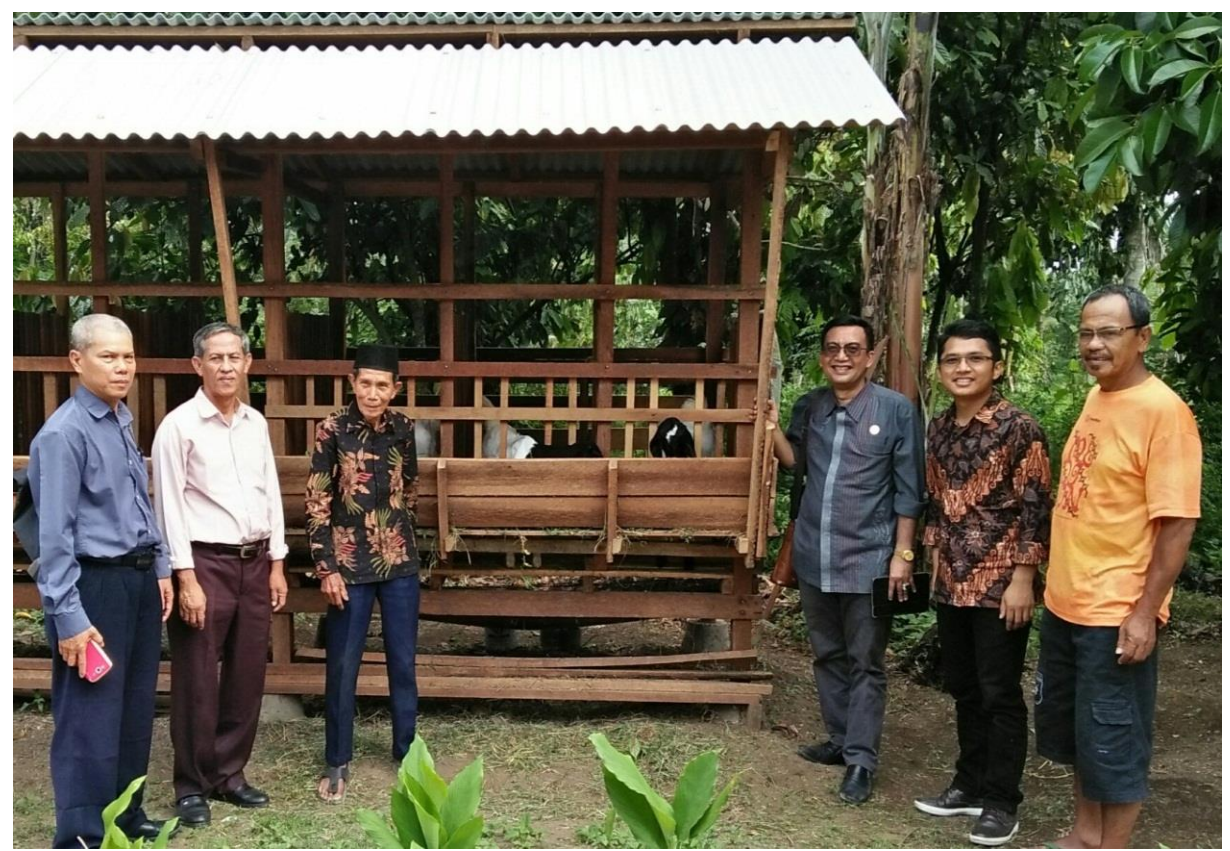

Gambar 2. Tim pengabdian meninjau mitra sebagai percontohan budidaya kambing etawa 
Pengabdian kepada masyarakat ini, selain melibatkan dua mitra dari masyarakat peternak juga melibatkan Dinas Pertenakan Kabupaten Lima Puluh Kota dan Politani Payakumbuh. Kerjasama dengan Politani Payakumbuh, terkait dengan pelatihan fermentasi pakan ternak. Tim Politani Payakumbuh dikoordinir oleh Ibu Muthia Dewi, S.Pt, M.Sc sebagai salah satu pakar pakan ternak di Prodi Pertenakan Politani Payakumbuh. Tim Politani Payakumbuh berkerjasama dengan tim pengabdian UNP memberikan pelatihan fermentasi pakan ternak pada program pengabdian kepada masyarakat ini.Kerjasama dengan Dinas Pertenakan Kabupaten Lima Puluh Kota, selain tempat kegiatan pengabdian berada di wilayah ini, tim pengabdian UNP juga melibatkan petugas Penyuluh Pertenakan dari Dinas Pertenakan Kabupaten Lima Puluh Kota dalam memberikan Penyuluhan tentang Budidaya peternakan kambing Etawa, terutama terkait dengan manajemen dan kesehatan hewan ternak.

Selain itu, untuk meningkatkan kualitas pertumbuhan kambing etawa tim pengabdi UNP juga bekerjasama dengan Balai Pembibitan Ternak Unggul dan Hijauan Pakan Ternak (BPTUHPT) Padang Mengatas. Dalam hal ini bapak Yose, L Marta, S.Pt, M.Pt, selaku penaggungjawab BPTUHPT Padang Mengatas, banyak memberikan informasi tentang tanaman pakan ternak, "Indigofera" untuk dijadikan sebagai pakan alternatif budidaya kambing etawa bagi mitra pengabdian. Tim pengabdian UNP juga diperkenalkan pada tanaman indigofera yang sudah dibudidayakan di perkebunan BPTUHPT Padang Mengatas dan memberikan sampel tanaman indigofera yang sudah siap untuk diberikan kepada ternak, serta memberi sampel benih tanaman indigofera untuk dibudidayakan di tempat mitra pengabdian.

Indigofera merupakan tanaman dari kelompok kacangan (family: Fabaceae) dengan genus Indigofera dan memiliki 700 spesies yang tersebar di Benua Afrika, Asia dan Amerika Utara. Sekitar tahun 1900 Indigofera dibawa ke Indonesia oleh kolonial Eropa serta terus berkembang secara luas. Sekitar 40 spesies berkembang pesat di wilayah Asia Tenggara. Indigofera jenis Arrecta dan Cordifola merupakan jenis yang banyak terdapat di Indonesia. Keunggulan indigofera adalah: (1) Protein kasar sekitar 22-30\%, serat kasar 15-17\%, kalsium 0,22\% dan fosfor 0,18\%; (2) Memiliki tanin yang rendah berkisar antara 0,6-1,4 ppm sehingga palatabilitas baik dan tidak menimbulkan anti nutrisi; (3) Tingkat kecernaan tinggi (77\%); (4) Toleran terhadap berbagai kondisi lingkungan seperti musim kering, genangan air dan tahan terhadap salinitas sehingga dapat menjadi sumber pakan sepanjang tahun; (5) Memiliki biomassa daun yang tinggi sehinga dapat digunakan sebagai pembuatan bahan pakan kaya protein. (Direktorat Pakan Direktorat Jenderal Peternakan dan Keswan, 2014).

Pemilihan bibit kambing menjadi penting, untuk itu tim pengabdian UNP melakukan survei ke beberapa tempat, diantaranya ke lokasi bibit kambing etawa di desa Puluthan Tanjungpati Kecamatan Harau (2-7-2019). Di tempat ini ada budidaya kambing etawa yang dikelola oleh bapak Mukhlis, jumlah kambing etawa beliau ada sekitar 30-an dan ada 5 ekor yang sedang dibibitkan. Tim pengabdi bersama dengan mitra melakukan pengamatan terhadap anak-anak kambing pak Mukhlis tersebut dan dari hasil pengamatan anak atau bibit kambing etawa yang dikelola oleh bapak Mukhlis ini ternyata lebih bagus dari yang kami survei sebelumnya di daerah kelurahan Ibuh Kota Payakumbuh. Akhirnya kami tim pengabdian dan mitra menetapkan untuk memesan bibit kambing etawa dari pertenak bapak Mukhlis ini. Bapak Mukhlis juga sudah mengembangkan pertenakan kambing etawa ini untuk mengolah susu kambing etawa untuk dijual. Bapak Mukhlis dapat menghasilkan 2 liter per hari dari satu induk kambing etawa, lalu dimasukkan pada gelas plastik ukuran $200 \mathrm{~mm}$ dan dijual dengan harga $\mathrm{Rp}$. 5.000 satu gelas plastik tersebut. Jadi 1 liter susu kambing etawa bisa menghasilkan Rp. 25.000. Untuk pakan kambing etawa bapak Muhklis masih menggunakan pakan konvensional yakni dari rerumputan dan dedaunan terutama daun ubi kayu. 


\section{Suluah Bendang: Jurnal Ilmiah Pengabdian Kepada Masyarakat}

Vol19, No.2, 2019

Rusdi, Wahidul Basri, Aldi Frinaldi, Uun Lionar

Adapun kegiatan pengabdian kepada masyarakat ini terdiri dari dua kegiatan yakni: (1) Pembuatan kandang dan pengadaan bibit percontohan kambing etawa yang sudah dilaksanakan sejak tanggal 26 Juni s/d 6 Juli 2019 di Jorong Padang Ambacang untuk dua orang mitra pengabdian yakni bapak Biko Ario Putra dan bapak Darani. Penentuan mitra pengabdian ini melalui survei lapangan yang dilaksanakan tanggal 26-27 Juni 2019; (2) Pelatihan dan Penyuluhan Budidaya kambing Etawa di Jorong Padang Ambacang Nagari Batu Balang Kecamatan Harau Kabupaten Lima Puluh Kota, bertempat di Kantor Wali Nagari Batu Balang. Kegiatan ini dilaksanakan pada tanggal 6-7 Agustus 2019, dengan inti kegiatan sbb: (1) Sambutan oleh ketua Tim Pengabdian UNP oleh Bapak Dr. Rusdi, M.Hum, sekaligus sosialisasi budidaya ternak kambing etawa; (2) Sambutan Wali Nagari Batu Balang oleh Bapak Dasril Syofiadi; (3) Penyuluhan tentang budidaya kambing etawa dari Dinas Pertenakan Kabupaten Lima Puluh Kota oleh dr. Hewan, Ibu Noviyanti dan Ibu Erawati; (4) Pelatihan tentang fermentasi pakan ternak kambing etawa dari tim Politani Payakumbuh yang dipimpin oleh Ibu Yurni, SPt, M.Sc.

Kegiatan penyuluhan dan Pelatihan ini diikuti oleh 20 orang perternak atau peminat perternak yang mewakili masing-masing Jorong yang ada di Nagari Batu Balang. Penyuluhan dan Pelatihan ini mendapat respon yang positif dari peternak dan calon peternak dari peserta. Hal ini nampak dari banyaknya pertanyaan dari perserta terutama tentang manajemen pertenakan dan fermentasi pakan ternak serta yang lebih penting lagi tentang pemeliharaan kesehatan ternak.

\section{Luaran}

Luaran wajib, yaitu satu artikel ilmiah yang dipublikasikan melalui Jurnal ber ISSN atau prosiding dari seminar nasional; dan satu artikel pada media masa/elektronik serta video kegiatan dengan durasi $3 \mathrm{~s} / \mathrm{d} 4$ menit. Luaran tambahan, (1) Publikasi pada media masa cetak/ online/repocitory PT; (2) Peningkatan daya saing (peningkatan kualitas, kuantitas, serta nilai tambah khususnya tentang peternakan kambing etawa; (3) Peningkatan penerapan iptek di masyarakat terkait dengan tehnologi sederhana tentang fermentasi pakan ternak kambing etawa dan manajemen peternakan.

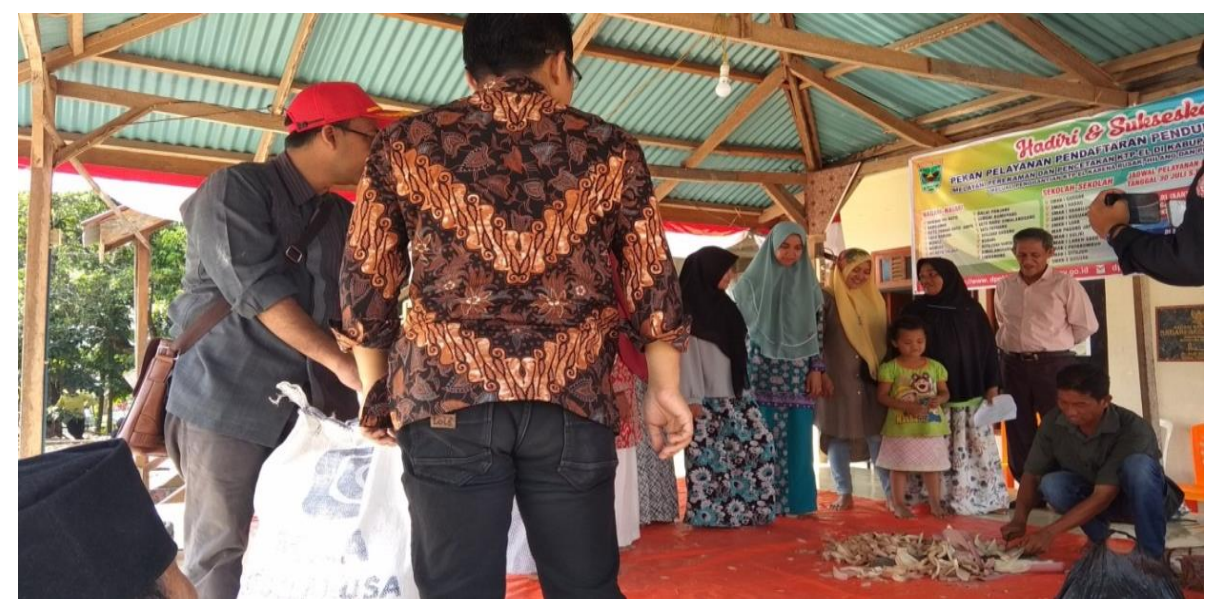

Gambar.3 Praktek pembuatan fragmentasi pakan ternak kambing etawa berbahan baku pelepah pisang, dedak dan ampas tahu. 


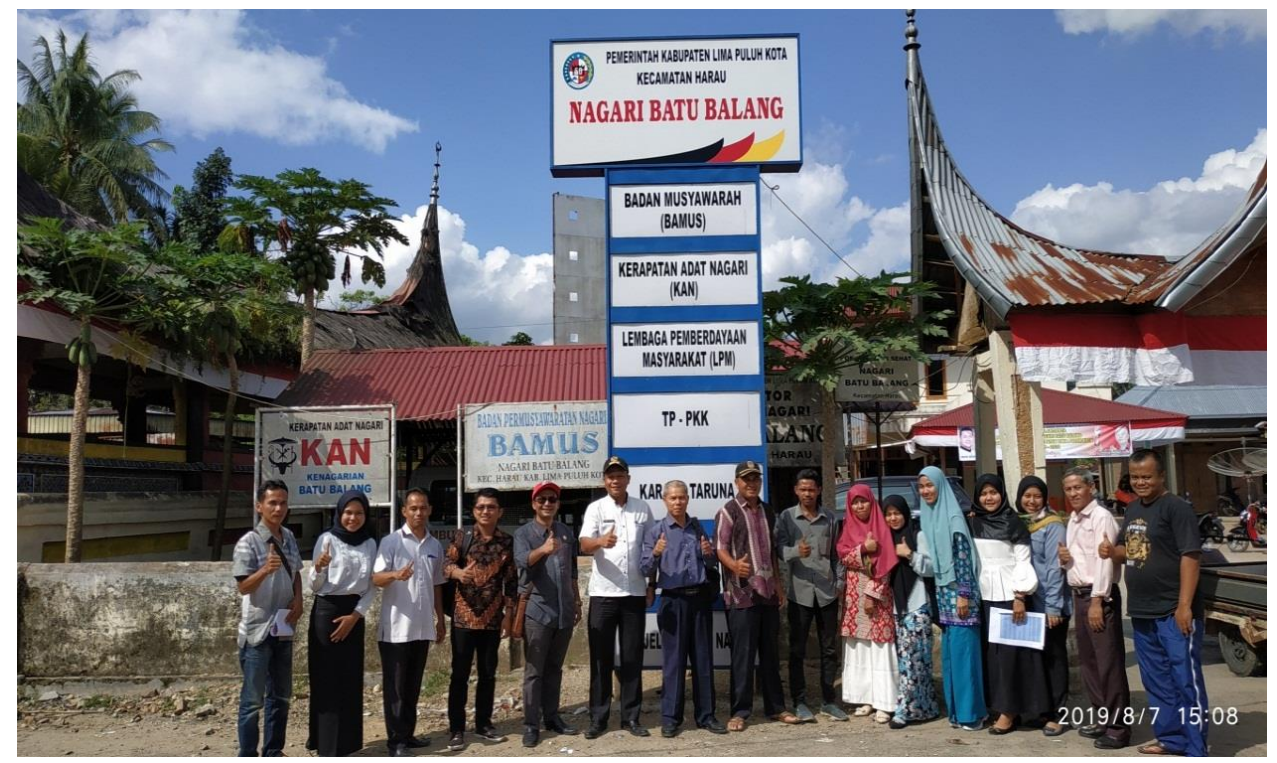

Gambar 4. Tim pengabdian UNP foto bersama dengan Wali Nagari \& staf serta mitra kerjasama Politani Payakumbuh dan Dinas Pertenakan Kabupaten Lima Puluh Kota

\section{KESIMPULAN}

Melalui penerapan teknologi dan inovasi terkini, cara ternak kambing modern dinyatakan lebih intensif. Cara ternak kambing modern yang perlu diterapkan adalah diantaranya manajemen kandang kambing, manajemen bibit kambing, manajemen pakan kambing, dan manajemen pemeliharaan kambing. Supaya usaha ternak kambing cepat berhasil, menggunakan cara beternak kambing secara modern dan propfesional seperti fermentasi pakan ternak kambing termasuk cara beternak kambing yang baik dan benar. Beternak kambing secara modern memiliki banyak keunggulan, diantaranya yaitu efisiensi biaya, waktu, tenaga kerja, pakan dan manajemen pengelolaan. Ternak kambing modern ini dapat diterapkan dalam berbagai skala usaha, mulai dari skala usaha kecil menengah, hingga ternak kambing modern. Kegiatan pengabdian kepada masyarakat tentang budidaya kambing etawa ini mendapat respon positif dari masyarakat Nagari Batu Balang Kecamatan Harau Kabupaten Lima Puluh Kota. Masyarakat berharap kegiatan seperti ini bisa berlanjut untuk tahun-tahun mendatang.

\section{DAFTAR PUSTAKA}

Direktorat Pakan Direktorat Jendral Pertenakan dan Keswan, INDIGOFERA, 2014, Jakarta.

Hera Wasiati1, Edi Faizal, PETERNAKAN KAMBING PERANAKAN ETAWA DI KABUPATEN BANTUL, Jurnal ABDIMAS Unmer Malang Vol. 3, Nomor 1, Juni 2018

Sarwono, B., 2011, Beternak Kambing Unggul, PT. Penebar Swadaya, Jakarta.

Setiawan, T. dan Tanius, 2008, Beternak Kambing Perah Peranakan Etawa, PT. Penebar Swadaya, Jakarta. 
Suluah Bendang: Jurnal Ilmiah Pengabdian Kepada Masyarakat

Vol19, No.2, 2019

Rusdi, Wahidul Basri, Aldi Frinaldi, Uun Lionar

Sodiq, A. dan Zainal, A., 2008, Meningkatkan Produksi Susu Kambing Peranakan Etawa, Agromedia Pustaka, Jakarta.

PANDUAN PELAKSANAAN PENGABDIAN KEPADA MASYARAKAT, Edisi Revisi, Lembaga Penelitian dan Pengabdian Kepada Masyarakat Universitas Negeri Padang, Kementerian Riset Teknologi dan Pendidikan Tinggi 2019 